\title{
K ROLI ABDUKCE V PRÁVNÍM MYŠLENÍ ANEB JAK POZNATKY O ABDUKCI MOHOU ZVÝŠIT PRO-SYSTÉMOVOST INTERPRETACE A APLIKACE PRÁVA*
}

\author{
KATARZYNA ŽÁK KRZYŽANKOVÁ
}

\begin{abstract}
On Abduction in Legal Thinking or How Knowledge of Abduction Can Increase Pro-systemic Legal Interpretation and Application

The paper deals with the issue of abduction. First of all, the paper presents the development of the concept of abduction in the work of Charles S. Peirce, who was the first in modern history to examine abduction and suggested its two partially different concepts; namely abduction as one of the basic types of logical inferences, and - later - as a necessary stage in any process of creating new hypotheses or theories explaining a certain phenomenon, where abduction allows to generate explanatory hypotheses and to choose from possible explanations that appear to be the most appropriate in the given case. The catalogue of criteria that, according to Peirce and his followers, make it easier to select the best explanatory hypothesis is also presented. Attention is paid to Peirce's consideration about the nature of human abduction reasoning. The analysis is supplemented by introduction of two basic directions in contemporary research in this field. In the second part, the paper identifies the basic types of cases which we encounter with abductive reasoning in legal thinking. Particular attention is paid to its use in practical thinking, namely situations where abduction reasoning contributes to finding a causal explanation of a certain legal-relevant phenomenon, to a legal assessment of the facts and to the formulation of an interpretative conclusion of an unclear provision. It is considered how the criteria determining the selection of the explanatory hypothesis, as well as knowledge of abduction itself, can contribute to pro-systemic legal interpretation and application, thus helping to reduce irrationality and arbitrariness of these processes. In examining this issue, one of the main problems of contemporary legal science and practice is identified, namely the absence of sufficient interpretative rules regulating conflicts between interpretative conclusions obtained on the basis of various interpretative methods.
\end{abstract}

Keywords: abduction; inference to the best explanation; Ch. S. Peirce; G. Harman; criteria for choosing the best explanation; systematism; legal decision making

Klíčová slova: abdukce; inference k nejlepšímu vysvětlení; Ch. S. Peirce; G. Harman; kritéria výběru nejlepšího vysvětlení; systémovost; právní rozhodování

DOI: $10.14712 / 23366478.2019 .40$

* Tento př́spěvek vznikl v rámci plnění projektu Grantové agentury ČR reg. č. 19-10723S „Co současné právo sjednocuje a co jej fragmentarizuje z pohledu současné právní teorie a soudní praxe?“". 


\section{1. ÚVOD}

V tuzemských učebnicích určených budoucím právníkům většinou nenalézáme zmínku o abdukci, ačkoliv - vedle indukce a dedukce - bývá řazena mezi základní druhy (právního) usuzování. ${ }^{1}$ Poznatky o abdukci zůstávají stranou pozornosti i širší odborné právní veřejnosti, a to i přesto, že analyzují a vysvětlují způsoby vytváření a prijímání nových hypotéz. Pojednávají tedy o mechanismech, které jsou stěžejní, ba nenahraditelné z pohledu každodenní činnosti právníků. S generováním i přijímáním vysvětlujících hypotéz se totiž setkáváme jak v oblasti praktické (zejména v rámci aplikace práva, a to při řešení tzv. otázek skutkových i otázek právních), tak při vědecké práci.

Znalost abdukční problematiky umožňuje lépe strukturovat, racionalizovat a dílem i zpětně verifikovat tyto procesy. Legitimizuje se tak i potřebnost a smysluplnost teoretických zkoumání abdukce, které ve svém důsledku mohou přispět k pro-systémovému chování osob v situacích, kdy pracují z pohledu práva/právní vědy s různými relevantními vysvětlujícími hypotézami. ${ }^{2}$

Vzhledem $\mathrm{k}$ ne zcela uspokojivému stavu diskurzu na dané téma $\mathrm{v}$ tuzemském právním prostředí, ${ }^{3}$ který může bránit širšímu využití dosavadních poznatků o abdukci, popř. vést $\mathrm{k}$ jejich částečně zkreslené aplikaci, ${ }^{4}$ jeví se jako potřebné nejdříve přiblížit pojem abdukce. Pozornost však bude věnována pouze jednomu z možných významů tohoto polysému, a to konkrétně tomu, jenž abdukci prriřkl Charles Sanders Peirce (1839-1914), „beze vši pochybnosti... jeden z nejoriginálnějšich intelektů 19. století a nepochybně největši americký myslitel ${ }^{*}, 5$ ne-li dokonce dle názoru některých ,jeden $z$ největšich filozofů všech dob", 6 a o němž - vzhledem k uvedenému poněkud paradox-

1 Výjimku z pravidla představuje Štěpánova učebnice Logika a právo, ve které abdukci jakožto jednomu „z možných typů pravděpodobnostnich úsudkư“ (s. 50) věnuje čtyři stručné odstavce svého textu. Bliže: ŠTĚPÁN, J. Logika a právo. Praha: C. H. Beck, 2001, s. 50-51.

2 Právní věda a jí nabízené poznatky jsou způsobilé ovlivňovat podobu ,živého“ " práva i formy jeho realizace ze strany k tomu kompetentních členů společnosti. Blíže BERGER, L. P. - LUCKMANN, T. Sociální konstrukce reality. Pojednání o sociologii védění. Brno: Centrum pro studium demokracie a kultury (CDK), 1999, passim.

3 Jediný ucelenější rozbor dané problematiky nabízejí práce z pera T. Sobka, který však důsledněji nerozlišuje mezi různými pojetími abdukce v díle Peirceho a u jeho následovníků. V Sobkově pojetí je též abdukce spojována jen $\mathrm{s}$,formul(aci) hypotézy o kauzální souvislosti mezi známými fakty, (přičemž)... (t)yto hypotézy nejsou poznáváním nových faktů, ale pouze možným způsobem, jak porozumét známým faktům tím, že jsou uvedeny do souvislosti..." (SOBEK, T. Právni myšleni. Kritika moralismu. Praha: Ústav státu a práva, 2011, s. 182). Některé soudobé práce věnované abdukci přitom rozšiřují oblast využití abduktivních inferencí i na jiné než ryze kauzální a fyzikální spojitosti.

4 V poslední době lze zaznamenat určitý, byt’ spíše stále jen sporadický, nárůst odkazů na abdukci v odborných tuzemských právních textech. Jak bude níže podrobněji rozvedeno, lze mít určité pochybnosti, zda těmto poukazům předchází hlubší znalost problematiky abdukčního usuzování. Kupř́íkladu J. Kokešová ve své stati Ústavni soud a reprezentace lidu: abduktivní inference zveřejněné v červnovém čísle letošního ročníku Právníka volí ,abduktivní metodu“ (s. 575), aby vysvětlila „mechanismus, kterým se může vi̊le lidu uplatnit při výkladu zákona Ústavním soudem" (s. 575), přičemž upozorňuje, že jde jí o „otevřeni nových myšlenkových cest, nikoliv jejich testování, (nebot') abduktivni závěry mohou být pr̆iznaně spekulativni" (s. 576). Pomíjí tedy skutečnost, že dle názorů Peirceho nelze jakoukoliv vysvětlující hypotézu bez dalšího označit za „abduktivní inferenci“.

5 RUSSELL, B. Wisdom of the West. New York: Doubleday, 1959, s. 276.

6 POPPER, K. Objective Knowledge: An Evolutionary Approach. Oxford: Clarendon Press, 1972, s. 212. 
ně - „většina lidí nikdy predtím neslyšela“ ${ }^{7}{ }^{7}$ Další možné významy slova abdukce, tedy at' použivané v medicíně k popisu upažení, ${ }^{8}$ či v anglosaském světě $\mathrm{k}$ označení únosu lidí, ${ }^{9}$ budou pominuty.

V rámci rozboru Peircova vědeckého odkazu přitom budou představeny oba návrhy abdukce, které v průběhu svého života formuloval. Ukážeme si tedy jak jeho rané názory zastávané přibližně do roku 1900, kdy je abdukce Peircem vykreslována jako jeden ze základních typů logických úsudků, tak i pozdější úvahy, kdy se abdukce stává výchozím prvkem či etapou jakéhokoliv procesu (vědeckého) objevování a kdy se rovněž Peircovo úsilí začíná stále intenzivněji soustředit na zdůvodnění abdukčního usuzování jako takového. Následná kritika (či snad i nepochopení?) některých tezí z Peircova odkazu pomůže ukázat, jakým směrem evoluovalo v průběhu 20. století poznání o abdukci.

Na tuto první, spíše analyticko-popisnou část, jejíž těžiště bude spočívat v oblasti logiky a obecné metodologie vědy, navážou úvahy zaměřené na oblast práva a právní vědy. Bude přitom zejména zkoumáno, v jakých situacích právníci - praktici i teoretici - využívají abdukci, a tedy, kdy poznatky o abdukčních inferencích a zejména pak kritéríích pro výběr nejlepšího vysvětlení mohou přispět k pro-systémovému pohledu na právo (resp. i právní vědu) a jeho realizaci.

\section{ABDUKCE, DEDUKCE A INDUKCE - PRVNÍ PŘIBLÍŽENÍ}

Pro rozsáhlé a nesmírně různorodé vědecké dílo „otce pragmatismu a sémiotiky ${ }^{\text {"10 }} \mathrm{Ch}$. S. Peirce je př́iznačné, že ústřední místo v něm zaujímá koncepce abdukce. Sebe sama přitom Peirce vnímá jako jakéhosi „,průzkumníka na neprobádaném území" (explorer upon untrodden ground),$^{11}$ byt' toto hodnocení není zcela přesné, nebot' částečně navazuje na úvahy svých velkých předchůdců, jako byl Aristoteles či I. Kant.

7 PERCY, W. The divided creature. The Wilson Quarterly, 1989, vol. 13, s. 80. Autor této věty však současně předpokládá, že se to s postupem doby změní. O správnosti této predikci přisvědčuje recentní vývoj, nebot' od poloviny 70. let minulého století lze pozorovat nárůst zájmu vědecké komunity o bohatý, nesmírně různorodý, byt' dodnes ne zcela utříděný odkaz Ch. S. Peirce, ve kterém nechybí poznatky z oblasti astronomie, meteorologie, geodézie, matematiky, logiky, filozofie, teorie a historie vědy, sémiotiky, lingvistiky a ekonomie či třeba psychologie. Ve všech těchto pracích je přitom určitý spojující prvek - snaha porozumět logice vědeckého objevu, v důsledku čehož koncepce abdukce proniká do stále dalších vědních odvětví jako je logika, filozofie, lingvistika či právo. K odkazu Peirceho a jeho hodnocení srov. blíže NUBIOLA, J. Abduction or the logic of surprise. Semiotica. Journal of the International Association for Semiotic Studies, 2005, Issue 153-1/4, s. 118-120.

8 Srov. Ottův slovní naučný. Ilustrovaná encyklopedie obecných vědomostí. První díl. A - Alpy. Praha: Paseka-Argo, 1996, s. 38, heslo ,abdukce“. Opakem je ,addukce“ čili ,přripažení“.

9 V tomto významu je daný termín používán i v některých mezinárodně-právních dokumentech. Srov. např́klad Haagskou úmluvu o občanskoprávních aspektech mezinárodního únosu dětí (Hague Convention on the Civil Aspects of International Child Abduction) ze dne 25. října 1980, která byla vypracována Haagskou konferencí mezinárodního práva soukromého a v tuzemsku byla vyhlášena pod č. 34/1998 Sb.

10 NUBIOLA, c. d., s. 118. Sebrané spisy Peirceho (Collected Papers of Charles Sanders Peirce) jsou dostupné na: https://colorysemiotica.files.wordpress.com/2014/08/peirce-collectedpapers.pdf [cit. 25. 6. 2019]. Není-li dále uvedeno jinak, veškeré citace či odkazy na Peircovy práce byly převzaty z tohoto zdroje.

11 Collected Papers of Charles Sanders Peirce, Vol. 2, § 102, CP 2.102, c. d. 
V rámci studia Aristotelových Prvnich analytik si totiž Peirce všímá, že tento antický myslitel rozlišoval kromě dedukce (synagoge neboli též anagoge) a indukce (epagoge) ještě jeden základní způsob úsudků - apagoge (do angličtiny se tento termín někdy překládá i jako „abdukce“) čili „redukci“. „Redukce... (však nebyla do jeho časů - pozn. aut.) správně pochopena z důvodu narušeného (corrupt) textu,"12 což se Peirce snaží v sérii svých článků změnit. Zastává přitom názor, že doposud se logikové soustředili jen na ty způsoby usuzování, které vedou k jistým (platným) závěrům, a opomíjeli dle jeho soudu neméně významné formy úsudkủ, jejichž kvalita spočívá ve schopnosti generovat nové poznatky (byt' správnost a jistotu nemusejí vždy nutně garantovat). Jinými slovy, Peirce plédoval pro dvou-dimenzionální př́stup při zkoumání způsobů usuzování, v rámci kterého by byly analyzovány i nededuktivní inference, mezi něž řadí jednak indukci, jednak abdukci. ${ }^{13}$

Do obecnějšího povědomí se tyto myšlenky dostávají díky popularizujícímu článku Deduction, Induction, and Hypothesis, jenž byl otištěn v roce 1878 v srpnovém čísle časopisu Popular Science Monthly v rámci Peircovy pravidelné rubriky, či spíše série přednášek Illustrations of the Logic Science. ${ }^{14}$ Zde své čtenáře upozorňuje, že vedle klasických typů usuzování je třeba rozlišovat ještě jeden základní způsob inference, který ve svých pracích zprvu označuje jako „hypotézu“ (hypothesis), „dobrý odhad“ (fair guess), ,pravděpodobnost“" (probability) či ,předpoklad“ (supposition), postupně zejména po roce 1900 - stále častěji jako ,abdukci“ (abduction). ${ }^{15}$

Jako základ pro vysvětlení rozdílů mezi deduktivním (analytickým) uvažováním na straně jedné a syntetickými inferencemi, jež jsou způsobilé vytvářet nové poznatky ${ }^{16}$

12 PEIRCE, C. S. Lessons from the History of Science. In: Collected Papers of Charles Sanders Peirce, Vol. $1, \S 65$, CP 1.65 , c. d. Arisoteles přitom, „redukci rozumi (1) důkaz, ve kterém prvni termín (vétší) zjevně prospivá střednímu, ale vztah středního k nižšímu neni zjevný, nicméně je více či méně pravděpodobný jako závěr; (2) bud' takový důkaz, ve kterém vystupuje několik nepř́mých termínu mezi menším a středním termínem; nebot’ v každém takovém prípadě nastává přibliženi se k poznáni" (ARYSTOTELES Analityki pierwsze. In: Týž: Kategorie. Analityki pierwsze. Analityki wtóre. Warszawa: Wydawnictwo Naukowe PWN, 2013, s. 204, kap. 25, 64a20). Dodejme, že Aristoteles vyčleňoval i analogii (paradeigma), která však dle Peirceho ,má povahu dílem indukce, dílem retrodukce“(CP 1.65).

13 „Domnivám se, že logici by měli mit dva hlavní cile: zaprvé, ukázat stupeñ a druh jistoty (př́stup k jistotě - approach to certainty) každého způsobu usuzování; zadruhé, ukázat možnou plodnost (uberty) nebo hodnotu produktivity (value in productiveness) každého způsobu (usuzováni)" (Collected Papers of Charles Sanders Peirce, Vol. 8, § 384, CP 8.384, c. d.).

$14 \mathrm{~V}$ jediné poznámce pod čarou $\mathrm{k}$ tomuto článku Peirce upozorňuje, že dělení logických inferencí prvně představil v roce 1866 v rámci cyklu přednášek v Lowellově Institutu v Bostonu. Srov. PEIRCE, C. S. Deduction, Induction, and Hypothesis. Illustrations of the Logic of Science VI. Popular Science Monthly, 1878, vol. 13, August, s. 482.

15 Všechna tato označení - $\mathrm{s}$ výjimkou abdukce - se vedle sebe objevují v předmětném př́spěvku. Termín „abdukce“ totiž Peirce zprvu odmítal, nebot’ dle jeho soudu se jednalo o zkomolený anglický překlad řeckého ,apagoge“. Lze upozornit, že dodnes někteří autoři nepoužívají pro první Peircovo pojetí „abdukce“ toto označení, a to aby i terminologicky odlišili obě koncepce abdukce. Př́íkladem tohoto př́istupu jsou třeba studie S. Psillosa. Srov. PSILLOS, S. An Explorer upon Untrodden Ground: Peirce on Abduction. In: GABBAY, D. M. - HARTMANN, S. - WOODS, J. (eds.). Handbook of the History of Logic. Volume 10: Inductive Logic. Elsevier BV, 2011, s. 117-152.

16 Rozlišování inferencí na analytické a syntetické přebírá Peirce z Kantovy Kritiky čistého rozumu, byt' $\mathrm{v}$ částečně modifikované podobě. Dle Kanta „,analytické soudy jsou... ty, v nichž je spojení predikátu se subjektem myšleno prostřednictvím identity, ty pak, v nichž je toto spojeni myšleno bez identity, nazýv(á) syntetickými. První soudy... také... nazýv(á) soudy vysvětlujicími, druhé rozšiřujicími, nebot' vysvětlujicí soudy k pojmu subjektu nic nepřidávají, nýbrž je rozborem rozčleňnjí na jeho dilčí pojmy, které v ném již 
a mezi něž z počátku řadí indukci a abdukci, na straně druhé, používá dnes již ikonický př́iklad s pytlem fazolí. Na něm plasticky vysvětluje tři různé způsoby usuzování, jež určitá osoba bude provádět, aby mohla vyslovit závěr o barvě fazolí uskladněných v pytlích v místnosti, do které vchází. Pokaždé je přitom vybavena poněkud jinými vstupními informacemi. ${ }^{17}$

V prvním př́ipadě do místnosti vchází osoba, která ví, že zde jsou v pytlích uskladněné bílé fazole (obecné pravidlo). Pokud tedy určité fazole, jež leží na stole v místnosti, byly dříve uskladněné v některém z pytlů (konkrétní případ), pak - aniž se na ně musí podívat - ví, že mají bílou barvu (výsledek). Popsaná situace odpovídá deduktivnímu usuzování, pro něž je příznačné, že nepřináší žádnou novou informaci oproti tomu, co již bylo obsaženo ve vstupních premisách. Tyto inference plní dle Peirceho toliko úlohu určitých ,poutačů pozornosti““ (logical formula for paying attention), nebot' z řady faktů obsažených v premisách vybírají jeden, na který v závěru upozorňují. ${ }^{18}$ Jsou-li přitom premisy pravdivé, pak totéž lze vyslovit i ve vztahu k závěru. Žádná nová informace či argument totiž není s to ovlivnit pravdivost cestou dedukce přijatého závěru. Jde tak o př́klad tzv. monotonického usuzování. ${ }^{19} \mathrm{~V}$ rámci klasické logiky byla vypracována řada schémat dedukčních úsudků, ${ }^{20}$ přičemž zvolením vhodné struktury, bez ohledu na konkrétní obsah premis, lze vždy dospět k platnému (nikoliv nutně pravdivému) závěru. ${ }^{21}$ Samotný Peirce se přitom domníval, že ,dedukce spočivá vždy pouze v aplikaci obecného pravidla na konkrétní př́pad“. 22

byly (i když konfúzně) myšleny. Naproti tomu rozšǐrujici soudy přidávaji k pojmu subjektu predikát, který v něm vủbec myšlen nebyl a žádným jeho rozborem by z něj nemohl být vyvozen" (KANT, I. Kritika čistého rozumu. Praha: OIKOYMENH, 2001, s. 39, A7-B11). Peirce s touto distinkcí souhlasí, má však za to, že Kant zbytečně zúžil problematiku analytických a syntetických soudů pouze na predikátové výroky, a dále že nedostatečně vniťrně rozčlenil syntetické výroky (tj. nevyčlenil abdukci). Srov. PSILLOS, c. d., s. $118-119$.

17 Oproti originálu byl Peircův př́íklad zjednodušen o pravděpodobnostní úvahu.

18 PEIRCE, c. d., s. 482.

19 Klasická dvouhodnotová logika aristotelské tradice je monotonická, nebot' pro ni platí, že ,jestliže z množiny premis A pramení věta $p$, pak věta p musí vyplývat i z množiny premis $B$, pokud A je podmnožinou množiny B“"(STELMACH, J. - BROŻEK, B. Metody prawnicze. Kraków: Zakamycze, 2004, s. 85). K Tarského definici monotonie pak srov. HOLLÄNDER, P. Filosofie práva. 2., rozš. vyd. Praha: Vydavatelství a nakladatelství Aleš Čeněk, 2012, s. 239, poznámka pod čarou č. 550. Pokud tedy určitá logická koncepce počitá s tím, že status/hodnota argumentu objevujícího se v premise se může pod vlivem nových informací/ protiargumentů změnit, máme co dočinění s př́ípadem non-monotonických, tedy i neklasických, logik, ve kterých se obvykle počitá s více než dvěma možnými pravdivostními hodnotami.

20 Tato schémata mohou být využívána i v rámci právního uvažování. Typickými a v právní praxi intuitivně využívanými př́íklady dedukčního usuzování jsou tzv. pravidlo odloučení (modus ponens), dle kterého $\mathrm{z}$ implikace $(\mathrm{A} \rightarrow \mathrm{B})$ a antecedentu $(\mathrm{A})$ lze dovodit konsekvent $(\mathrm{B})$, či dále třeba pravidlo popírání důsledku (modus tollens), stanovící, že jestliže $\mathrm{A}$ implikuje $\mathrm{B}(\mathrm{A} \rightarrow \mathrm{B})$ a zároveň neplatí $\mathrm{B}(\neg \mathrm{B})$, neplatí ani $\mathrm{A}(\neg \mathrm{A})$. K těmto i dalším schématům dedukčních úsudků srov. KNAPP, V. - GERLOCH, A. Logika v právním myšlení. Praha: Eurolex Bohemia, 2001, s. 70-72.

21 Zopakujme, že o pravdivosti konkrétního závěru rozhoduje to, zda v úsudku použité premisy jsou pravdivé.

22 PEIRCE, c. d., s. 470. Dedukční úsudek lze proto dle Peirceho schematizovat následovně, popř. jej do této podoby převést:

Premisa 1: Pravidlo. (V̌sechny fazole v tomto pytli jsou bilé.)

Premisa 2: Konkrétní prípad. (Tyto fazole jsou z tohoto pytle.)

Závěr: Výsledek. (Tudiž, tyto fazole jsou bilé.) 
V druhém případě je situace odlišná v tom směru, že do pokoje vchází osoba, která nemá žádnou vstupní znalost o barvě fazolí, které jsou uskladněny v pytlích, a proto, aby určila jejich barvu, bude muset fazole $\mathrm{v}$ sáčcích nejdřive empiricky pozorovat. Otevře nahodile první pytel (případ) a vidí pouze bílé fazole (premisa - výsledek pozorování), což ji vede k obecnému závěru (pravidlo), že všechny fazole v tomto pytli jsou bílé. Tento závěr čili - obecněji - ,pravidlo ziskané pozorováním výsledku v určitém př́padě ${ }^{23}$ je získán cestou indukce, resp. indukční generalizace, ${ }^{24}$ a je jen pravděpodobný. Objevím-li jakoukoliv luštěninu téhož druhu, avšak jiné barvy (např. černou fazoli), a tedy přistoupí-li další premisa, může se podoba závěru změnit. Indukce je tak druhem non-monotonického, zpochybnitelného usuzování, jehož relevance (čili síla a stupeň přesvědčivosti a jistoty) se odvíjí od velikosti pozorovaného vzorku. ${ }^{25}$ Pravdivost vstupních premis automaticky neskýtá záruku pravdivosti a platnosti závěru.

I ve třetím př́ípadě naše osoba vchází do místnosti naplněné pytli s fazolemi různé barvy, což je patrné na první pohled. V jednom z pytlů vidí pouze bílé fazole (pravidlo), prričemž fazole téže barvy vidí na stole (závěr pozorování), z čehož usuzuje, že tyto fazole zřejmě pocházejí z pytle s ostatními bílými fazolemi, odkud je někdo dříve vzal (případ). $\mathrm{V}$ rámci této úvahy je opětovně formulován toliko pravděpodobný (zpochybnitelný) závěr, který však přináší zcela novou informaci, jež slouží k vysvětlení určitého jevu či fenoménu. Právě takovéto vysvětlující usuzování označuje Peirce slovem abdukce.

Jak indukci, tak abdukci spojuje, že jsou ve vztahu inverze $\mathrm{k}$ dedukci. Přesněji řečeno, dedukční úsudky nám poskytují jisté (platné) závěry, ale nepřinášejí nové poznatky (žádnou informaci, která by nebyla obsažena již v premisách). Abdukce (resp. i indukce) patří k méně jistým formám inferencí, ale její nepřehlédnutelná hodnota spočívá ve schopnosti generovat nové myšlenky. ${ }^{26}$ Za této situace však vzájemné odlišení abdukce

23 PEIRCE, c. d., s. 471.

24 Současní logikové obvykle rozlišují dva základní typy indukce. Jmenovitě indukční generalizaci (inductive generalization), která je znázorněna ve fazolovém testu a pro kterou je příznačné, že na základě zjištění určité vlastnosti u jednotlivě pozorovaných objektů patřících do určité společné třridy je dovozeno, že tuto vlastnost mají pravděpodobně všechny objekty dané třídy. Druhý typ představuje indukční specifikace (inductive specification), která umožňuje vyslovit závěr o určitém individuu, a to na základě jeho přináležitosti $\mathrm{k}$ jisté širší množině či třídě, a dále - což mnohdy není explicitně vyjádřeno - při zohlednění skutečnosti, že pro tuto množinu či třídu je př́iznačná určitá vlastnost. Blíže: BREWER, S. From Enthymeme to Argument: Logocratic Method and the Virtues and Vices of Arguments. In: WEINSTEIN, J. B. ABRAMS, N. - BREWER, S. - MEDWED, D. S. Evidence. Cases and Materials. 10th Edition. St. Paul, MN: Foundation Press, 2017, s. 122-128. Samotný Peirce pak ve své sedmé přednášce v Lowellově institutu nabízí vůči představenému dělení dílem alternativní a dílem propracovanější klasifikaci indukce. Vyčleňuje tak indukci (1) základní (rudimentary), dle které pokud neexistuje žádný důkaz pro A, pak máme vycházet z toho, že A není relevantní; (ii) predikční (predictive) - kdy ověřujeme určité na zkoušku přijaté závěry; (iii) statistickou (statistical) - jejíž kvalita i relevance se odvíjí od velikosti vzorku, který je testován. Tyto základní typy indukcí pak dále vnitřně člení na určité podtypy. V podrobnostech srov. Collected Papers of Charles Sanders Peirce, 7th Vol., § 110-130, CP 7.110-7.130, c. d., popřr. i na dalších místech tohoto díla (zejména CP 7.208 a násl.).

25 Pokud by byly všechny myslitelné případy verifikovány, pak síla závěru bude rovna dedukčnímu úsudku. K tzv. úplné (enumerativní) indukci srov. blíže: GOŁBA, F. - PIĘKOŚ, P. - TURKOWSKI, P. Logika dla prawników. Warszawa: C. H. Beck, 2012, s. 151-152, či ŠTĚPÁN, c. d., s. 50.

26 Tuto schopnost nemá žádný jiný způsob usuzování, tedy ani indukce. Indukce pracuje s větší mírou jistoty než abdukce, ale „produktivní“ se stává pouze v kombinaci s abdukcí - viz níže poznámky k abdukční indukci. Někteří proto indukci vnímají jako určitý „středový“ mód inferencí. SVENNEVIG, J. Abduction 
a indukce nemusí být na první pohled vždy zřejmé, a proto mu obvykle v minulosti nebyla dle Peirceho věnována větší pozornost.

Nicméně lze zmínit, že již J. S. Mill (1806-1873) si všímá rozdílu mezi ověřováním určité hypotézy př́značným pro indukční usuzování a samotným nalézáním hypotéz invencí. Ve svém spise A System of Logic Ratiocinative and Inductive z roku 1843 píše: „Dr. Whewell (významný logik žijící v jeho době - pozn. aut.).. nenazývá indukcí nic, kde není vnesena nová mentální koncepce, a vše indukcí, kde je. Ale tak se směšuje dvě velmi odlišné věci: invenci a drikaz."27 Obdobně jako později H. Reichenbach a K. Popper tedy Mill upozorn̆uje na rozdíl mezi ,kontextem objevu“ (v terminologii Milla „invencí') a „,kontextem ospravedlněni“" („důkazem“), ${ }^{28}$ byt' blíže tento fenomén nezkoumá.

Tato role historicky připadla právě Peircovi a znamená předěl v jeho dosavadním chápání abdukce. Ve snaze vysvětlit rozdíl mezi indukcí a abdukcí si začíná uvědomovat, že jeho původní úvahy nebyly zcela správné, nebot' - jak sám přiznává - byl přespř́liš ,okouzlen formou sylogismu a doktrínou logické extenze..., což vedlo k tomu, že jim pripisoval větši význam, než ve skutečnosti maji “. ${ }^{29}$ Reviduje tedy částečně svůj prvotní názor, že oba základní typy syntetických inferencíi ${ }^{30}$ odlišuje skutečnost, že indukce umožňuje formulovat obecné pravidlo o celé třídě či množině individuí na základě pozorování většího množství jejich vybraných zástupců. Abdukce pak vyžaduje „troufalejší a riskantnější krok“ (bolder and more perilous step). ${ }^{31} \mathrm{Na}$ jejím základě „dovozujeme existenci faktů zcela odlišných od jakýchkoliv, jež jsou pozorovány, ze kterých, dle známých zákonů či pravidel, něco pozorovatelného musí vyústit". ${ }^{32}$ Indukce je ,postupem od jednotlivého k obecnému. Kdežto abdukce od účinku k příčině. Indukce klasifikuje, abdukce vysvětluje. "33

as a methodological approach to the study of spoken interaction [online, cit. 25. 6. 2019]. Dostupné na: http://folk.uio.no/janengh/Norskrift/NORskrift103 tekst.pdf.

27 MILL, J. S. A System of Logic Ratiocinative and Inductive. (Editováno J. M. Robsonem). Toronto: University of Toronto Press, 1973, s. 304-305. Mill dále k tomu dodává: „Invence, ač mǔže být kultivována, nemůže být převedena na pravidlo; neexistuje věda, která by umožnila lidem uvažovat o tom, co bude vyhovovat jejich cíluim" (s. 285).

28 Termíny kontext objevu a kontext ospravedlnění zavádí H. Reichenbach. V díle Experience and Prediction, jež bylo prvně vydáno v roce 1938, uvádí: „Existuje velký rozdil mezi systémem logických vztahů a faktickým způsobem, jak myšlenkový proces probíhá... Známý rozdil mezi způsobem, ... jak myslitel nalézá tvrzení, a jakje predstavuje veřejnosti, dokládá tuto tezi. Zavedu pro ně termíny kontext objevu a kontext odůvodnéni" (REICHENBACH, H. Experience and Prediction: An Analysis of the Foundations and the Structure of Knowledge. Chicago: University of Chicago Press, 1961, s. 4 a 7). Dodejme, že Reichenbach byl obeznámen s úvahami Peirceho na téma abdukce, nicméně považoval ,je za naprosto nejasné, a to $z$ di̊vodu propojení psychologie védeckého objevu s logickými teoriemi vztahujícími se k pozorovaným fakti̊m" (PSILLOS, c. d., uvedený autor zde cituje z Reichenbachova díla On Probability and Induction z roku 1938).

29 Collected Papers of Charles Sanders Peirce, 2nd Vol., § 102, CP 2.102, c. d.

30 V druhém období Peircových úvah o abdukci, kdy je akcentováno, že, jde o jediný způsob usuzování, který poskytuje nové ideje, (se ale stává zřejmým, že abdukce představuje - pozn. aut.) jediný druh, který v tomto významu je syntetický" (Collected Papersof Charles Sanders Peirce, 2nd Vol., § 777, CP 2.777, c. d.).

31 PEIRCE, c. d., s. 475.

32 PEIRCE, c. d., s. 477. Cum grano salis lze tedy abdukci chápat i jako určité ,protažení indukce za limity našeho pozorováni" (s. 480).

33 PEIRCE, c. d., s. 477. 
Postupně totiž dospívá $\mathrm{k}$ názoru, že ve skutečnosti abdukci a indukci - tak jak byly představeny ve fazolovém testu - nerozlišuje žádný klíčový znak, a dále, že naznačená sylogistická reprezentace je pro zachycení skutečné abdukční inference př́iliš zužující. Jak v př́padě indukční generalizace, tak i abdukce se totiž v uvedeném fazolovém př́kladu snažíme předvídat způsob uspořádání věcí ve světě. To, co obojí odlišuje, je skutečnost, že indukce zahrnuje „,horizontální vyvozováni“", tedy na základě přímo pozorovaných objektů dospíváme k závěru o celé množině/tř́ídě, kdežto abdukce pracuje $\mathrm{s}$,vertikálním vyvozováním“, tedy vytváŕíme hypotézy o objektech, jež nejsou přímo pozorovány. ${ }^{34} \mathrm{~V}$ obou př́padech se ale vždy jedná o inferenci od konkrétního př́padu k celku, tedy o typ usuzování, jehož podstata zůstává indukční. ${ }^{35}$ Podstatu pravé abdukce (abduction proper) - jak níže ukážeme - přitom tvoří jen „usuzování, pomocí kterého vytváŕrime vysvétlujici hypotézy, a nikoliv inference od př́padu $k$ celku“. ${ }^{36}$ Zároveň si všímá, že generalizační indukce nepředstavuje pouze rozšíření určitého znaku příznačného pro člena určité třídy či množiny na celou tuto tř́du/množinu. Zahrnuje i interpretaci závěrů, vyhodnocování relevance těchto závěrů. Nedílným prvkem tohoto typu usuzování je tedy vždy i práce s určitou vstupní hypotézou, určitým odhadem, který předurčuje indukční testování. Jinými slovy, součástí indukce je abdukce, a bylo by proto přesnější hovořit o abdukční indukci (abductory induction). ${ }^{37}$

V dopise americkému filozofovi a teologovi Paulu Carusovi z července 1910 pak následovně shrnuje první fází svých bádání nad abdukcí: „rozdělení základních druhů usuzováni na tři typy...stále dle mého soudu má opodstatněný základ. Nicméně téměr ve všem, co jsem napsal pred začátkem století... (20. století - pozn. aut.) více či ménějsem smíchal hypotézu a indukci."38 Jak tedy nově uchopuje abdukci a indukci?

\section{KE ZPU゚SOBU VYTVÁŘENÍ HYPOTÉZ - DRUHÉ PŘIBLÍŽENÍ ABDUKCE}

Neúnavná cizelace i obhajoba koncepce abdukce postupně sedimentuje v názor, že „abdukce koresponduje s úkolem zavádění nových idejí ve vědě, ve světě, s kreativitou. Dedukce načrtává nutné a variabilní závěry, které by měly vyplývat, jestli hypotézy budou pravdivé. Indukce empiricky potvrzuje hypotézy na určitém vzorku připadů. Existuji tedy tři druhy usuzování, které se nevyskytuji samostatně nebo paralelně, ale integrovaně a kooperovaně v postupných krocích védecké metody."39

34 PSILLOS, c. d., s. 130.

35 Nepřekvapuje proto, že abdukce v prvotním - fazolovém - pojetí bývá řazena k induktivním formám usuzování. Srov. SINNOT ARMSTRONG, W. - FOGELIN, R. Understanding Arguments. An Introduction to Informal Logic. 9th ed. Cengage Learning, 2015, s. 195. Jiní autoři ji bez dalš́ho vyčleňují jako samostatný typ logických úsudků, tedy neupozorňují na Peircův posun v chápání abdukce (viz - poznámka pod čarou č. 2).

36 BELLUCCI, F. Eco and Peirce on Abduction. European Journal of Pragmatism and American Philosophy, 2018, X-1, s. 3. [online, cit. 25. 6. 2019]. Dostupné na: https://journals.openedition.org/ejpap/1122.

37 Collected Papers of Charles Sanders Peirce, 6th Vol., § 526, CP 6.526, c. d.

38 Collected Papers of Charles Sanders Peirce, 8th Vol., § 227, CP 8.227, c. d.

39 NUBIOLA, c. d., s. 123. Zlomová je v tomto směru stat' On the Logic of Drawing History from Ancient Documents z roku 1901, ve které Peirce prvně prezentuje svůj modifikovaný pohled na abdukci. 
Peirce tedy dospívá $\mathrm{k}$ trríprvkovému metodologickému schématu, který stojí za jakýmkoliv objevem, novou teorií či pouhou hypotézou a který ve svých pracích po zbytek života dále zkoumá. První fázi modelu představuje abdukce, tj. vědomé vytváření i výběr potencionálně nejvhodnější vysvětlující hypotézy. Jejím spouštěčem (trigger) je údiv pozorujícího subjektu nad určitým fenoménem. ${ }^{40}$ „Každý druh vědy začíná novým fenoménem, který negativně narušuje naše podvědomé očekávání. “41 Nejde však o jakoukoliv nepravidelnost $\mathrm{v}$ obklopujícím světě, nýbrž o něco, co vyžaduje naší vědomou pozornost, novou regulaci či pohled, díky nimž údiv zanikne a situace se stává pochopitelná i snesitelná pro vnímavého pozorovatele. ${ }^{42}$

Krásné prríklady takových nepravidelností lze nalézt $\mathrm{v}$ řadě prríhod z pera sira Arthura C. Doyla pojednávajících o soukromém detektivovi Sherlocku Holmesovi. Kupř́íladu v příběhu Střibrný lysáček (The Adventure of Silver Blaze) z roku 1982, v němž se vyšetřuje tajemné zmizení vynikajícího závodního koně Strríbrného lysáčka a usmrcení jeho trenéra Johna Strakera, vede Holmes tento rozhovor s Gregorym, detektivem Scotland Yardu:

\section{„Gregory: Existuje nějaká okolnost, na kterou byste mě chtěl upozornit? \\ Holmes: Zajímavé je chováni psa v noci. \\ Gregory: Pes ale nic v noci nedělal. \\ Holmes: To je právě ta kuriózní událost.“43}

Právě v absenci štěkání v době zločinu spatřuje Holmes neobvyklost, nebot' při běžném chodu věcí by hlídací pes reagoval hlasitým projevem na vniknutí cizí osoby do soukromých prostor. Toto narušení obvyklého chodu věcí vyvolává Holmesův údiv, který - aby pominul - jej vede k vyslovení domněnky, že pachatelem musel být někdo, koho pes dobře znal. ${ }^{44}$ Tato vysvětlující hypotéza - získaná cestou slavné Holmesovy tzv. „dedukční metody“45 - umožňuje racionalizovat průběh nastalé situace.

Co je zásadní a co některými komentátory Peircova díla bylo v minulosti přehlíženo či nedostatečně akcentováno, za vysvětlující hypotézu přijímanou cestou abdukce na zkoušku nelze označit jakoukoliv spekulativní domněnku. Z možných vysvětlení je třeba vybrat takové, které se jeví jako „rozumné nebo možné“ (reasonable or plausible). Musí být tedy s to vysvětlit všechna relevantní fakta či fenomény, které vyvolávají náš

$40 \mathrm{~V}$ tomto aspektu lze vidět paralelu s názorem Aristotela, že jakémukoliv poznání předchází úžas nad obklopujícím světem. Slovy samotného Aristotela: ,(j)ako dnes, tak v dřivějších dobách lidé začali filosofovat, protože se něčemu divili. Z počátku se divili záhadným zjevưm (ta apora), jež jim bezprostředně ukazovala zkušenost, a teprve potom ponenáhlu postupujice naznačenou cestou dospěli k záhadám významnějsím ... Ten pak, kdo pochybuje a diví se (aporón kai thaumazón), má vědomí nevédomosti...“ (ARISTOTELES Metafyzika. Praha: Rezek, 2003, s. 38, 982 b).

41 Collected Papers of Charles Sanders Peirce, Vol. 7, § 188, CP 7.188, c. d.

42 Peirce zastává názor, že pro př́rodu je př́iznačná nepravidelnost, a tudíž zaznamenáme-li kolem nás nějakou pravidelnost, je třeba zkoumat její původ (srov. Collected Papers of Charles Sanders Peirce, Vol. 7, $\S 189$ a $§ 195$, CP 7.189 a 7.195, c. d.). Současně ale dodává, že pokud dojde k porušení či odchylkám od určité pravidelnosti, je třeba vysvětlit jejich prř́činu (CP 7.199).

43 DOYLE, A. C. The Adventure of Silver Blaze [online, cit. 25. 6. 2019]. Dostupné na: file:///H:/Downloads /the-memoirs-of-sherlock-holmes-001-adventure-1-silver-blaze.pdf.

44 „Pochopil jsem význam mlčení psa, jeden pravdivý závěr pak vždy naznačuje ostatní. Simpsonův incident mi ukázal, že pes byl držen ve stájich, a přestože nékdo vyvedl koně, pes neštěkal dostatečně, aby vzbudil dva chlapy v podkroví. Je zřejmé, že noční návštěvník byl někdo, koho pes dobře znal“" (DOYLE, c. d.).

45 Je nasnadě, že Holmesova metoda má kvalitativně jinou povahu než inference, které jsme jako ,dedukčni“ označili výše. 
úžas. ${ }^{46}$ Musí být i souladné s naším předchozím poznáním či míněním (background beliefs). Vysvětlující hypotéza je tak vždy zasazována do určitého apriorního zkušenostního a vědomostního kontextu, který - nevzniknou-li o něm pochybnosti - musí respektovat. Hypotéza by měla být rovněž ,jednoduchá" ve smyslu kautel naznačených Ockhamem ${ }^{47}$ a dostatečná široká, aby vysvětlila či podchytila celý vysvětlovaný jev či fenomén. ${ }^{48}$ Konečně, hypotéza musí být způsobilá následného testování (sic), nebot' „(j)akákoli hypotéza mũže být prípustná, pokud neexistuji žádné zvláštni důvody pro její opak, za předpokladu, že je schopna experimentálního ověrení, a pouze do té míry, do jaké je takové ověřeni možné. To je přibližně doktrína pragmatismu، “49

$\mathrm{V}$ príkladu řešeném detektivem Holmesem by tedy bylo možné zaznamenanou neobvyklost (absenci štěkání psa) racionalizovat i pomocí jiných vysvětlujících domněnek, a to např́klad tak, že pes byl pachatelem otráven či uspán, nebo jej třeba v době zločinu uneslo UFO. Nicméně zásady, které mají ř́ídit abdukční inferenci, ${ }^{50}$ nás nutí odmítnout tyto varianty. Podstatu abdukce lze proto spatřovat ve vědomém vytvoření a výběru pokud možno toho nejracionálnějšího - hodnoceno ze strany exegeta - návrhu vysvětlujícího určitou (ne)pravidelnost. Abdukce přitom představuje jediný způsob, jak lze zavádět nové ideje či myšlenky ve světě. ${ }^{51}$

Dedukce - následující krok v Peircově modelu vědeckého objevu - umožňuje ,načrtávat možné a nutné... konsekvence ",52 jež plynou z abdukcí vybrané hypotézy př̌ijaté na zkoušku a které jsou způsobilé dalšího empirického testování, resp. ověření v praxi. ${ }^{53}$ Poslední fázi Peircova modelu pak tvoří indukce, $v$ rámci které je testována relevantnost vysvětlující hypotézy, a to cestou ověřování platnosti a správnosti konsekvencí (predikcí), k nimž jsme dospěli cestou dedukce. ,Když zjistíme, že predikce za predikcí bez ohledu na preferenci, kterou jim připisujeme, je ověřna v rámci experimentu, začínáme souhlasit, že hypotéza má své místo mezi védeckými výsledky."54

Schopnost formulovat vysvětlující hypotézy je přitom vlastní lidem jako živočišnému druhu. Abdukční řešení „, nám přicházi jako záblesk vhledu (flash of insight). Je to akt porozuměni či prožreni (act of insight), ačkoliv velmi nejistého poznání. Je pravdou, že riozné prvky hypotézy byly v naši mysli předtím; ale je to představa spojení v jeden celek toho, o čemž jsme nikdy předtím ani nesnili, že by bylo možné propojit, z čehož

46 Collected Papers of Charles S. Peirce. 7th Vol., § 235, CP 7.235, c. d.

47 Collected Papers of Charles S. Peirce. 7th Vol., § 220 a 221, CP 7.220 a 7.221, c. d.

48 Tamtéž.

49 Collected Papers of Charles S. Peirce. 5th Vol., § 197 (CP 5.197), c. d. Z citované pasáže je přitom zřejmé, že v tomto místě se úvahy o abdukci protínají s ústředním principem Peircova pragmatismu, ba abdukce se stává úhelným kamenem této filozofie. Jak totiž Peirce v témže kontextu lapidárně vysvětluje: „Jestliže pozorně zvažujeme otázku pragmatismu, vidíme, že není ničím jiným než otázkou logiky abdukce“ (Collected Papers of Charles Sanders Peirce. 5th Vol., § 196, CP 5.196, c. d.).

50 K podrobnému rozboru jednotlivých zásad srov. v sekundární literatuře: PSILLOS, c. d., s. 133-136.

51 Abdukce, ,zahrnuje všechny možné způsoby vysvětlujicího usuzováni, kdežto indukce zase všechny způsoby empirického ověrováni správnosti určitého vysvětleni" (PSILLOS, c. d., s. 146).

52 Collected Papers of Charles S. Peirce. 7th Vol., §206, CP 7.206, c. d. Peirce v téže souvislosti hovoří i o vytváření ,predikcí ohledně toho, jaké budou výsledky praktického testováni" (tamtéž).

53 Empirická verifikace některých predikcí může přicházet v úvahu až v budoucnosti (in futuro) a může být podmíněna adekvátním technologickým rozvojem.

54 Collected Papers of Charles S. Peirce. 7th Vol., \$206, CP 7.206, c. d. 
prameni nové návrhy před naším rozjímáním. “55 V průběhu testování lze zpochybnit správnost vysvětlující hypotézy. Nicméně Peirce má za to, že „lidský mozek musí být naladěn na pravdu věcí, aby bylo objeveno to, co jsme (v našich dějinách - pozn. aut.) již objevili $i^{\text {" }}{ }^{56}$ Jinak řečeno, lidské dějiny ukazují, že z řady možných vysvětlení určitého fenoménu jsme schopni relativně rychle a bez řady omylů vybírat ta, která se později ukazují jako pravdivá. Tato lidská schopnost či snad i určitá ,forma instinktu“ (Ch. S. Peirce) pravdivě vysvětlovat věci legitimizuje dle Peirceho potřebu rozlišování abdukce jako speciální fáze objevování i svébytnou formu logického usuzování. Stává se tak evidentní, že Peircovy úvahy o abdukci se opírají o určitou meta-abdukci, dle které je svět poznatelný, má rád a lidé jsou ho s to poznávat. ${ }^{57}$ Tato meta-abdukce má regulativní charakter, nebot' nás nutí určitým způsobem přemýšlet o světě, resp. i k němu přistupovat. „Ačkoliv víme, že řád světa nemusí (tj. deduktivně) odpovídat tomu, co si myslíme, musíme postupovat tak, jako by tato... korespondence existovala." ${ }^{\text {"58 }}$

Peirce má dále za to, že abdukci můžeme logicky schematizovat, což je jeden z hlavních argumentů pro rozlišování tohoto způsobu usuzování. V sedmé přednášce $O$ pragmatismu a abdukci z roku 1903 pak uvádí toto konkrétní schéma abdukce:

„Je pozorován překvapivý fakt $C$.

Pokud by A bylo pravdou, pak by se jev C stal samozřejmým.

Proto je rozumné předpokládat, že A je pravda." ${ }^{59}$

Již na první pohled je patrný určitý „paradox“. Snažíme se logicky zapsat proces, který na jednu stranu má být racionální a vědomý, současně se ale dovoláváme obtížně uchopitelné lidské kreativity a invence, či dokonce instinktu odhadnout správné řešení. ${ }^{60}$ Nejenom tato otázka se stala zdrojem pozdější kritiky Peircova - at' raného, či vrcholného - pojetí abdukce a podnítila další zkoumání této problematiky. Částečně též vedla k reinterpretaci dosavadního způsobu chápání Peircova vědeckého odkazu. Významnou osobností, která přispěla k soudobému zájmu o abdukci, byl H. Frankfurt.

\section{FRANKFURTOVA KRITIKA ANEB SMĚREM K SOUDOBÉ DISKUZI NA TÉMA ABDUKCE}

Americký filozof Harry G. Frankfurt (nar. 1929) ve své krátké stati Peirce’s Notion of Abduction z roku 1958 podrobil tvrdé kritice Peircovu koncepci abdukce včetně pokusů o její logickou strukturalizaci. $V$ prvé řadě upozornil a na řadě citací $\mathrm{z}$ díla

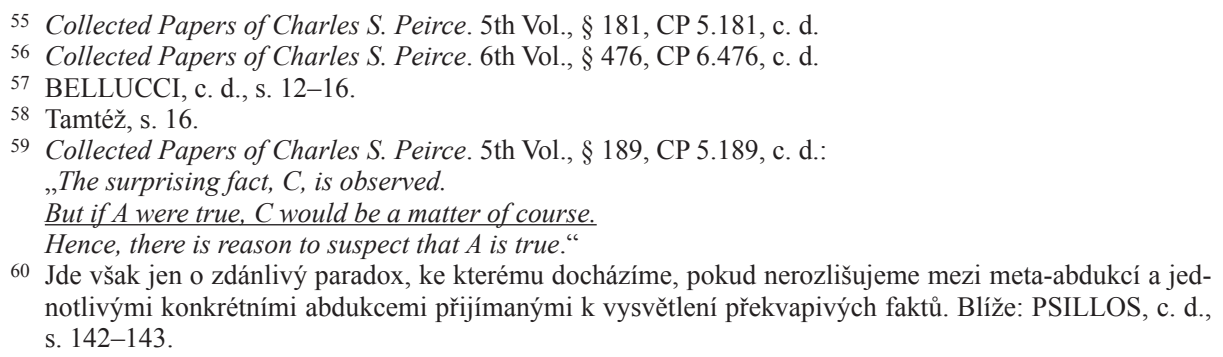

${ }^{60}$ Jde však jen o zdánlivý paradox, ke kterému docházíme, pokud nerozlišujeme mezi meta-abdukcí a jednotlivými konkrétními abdukcemi přijímanými $\mathrm{k}$ vysvětlení překvapivých faktů. Bliže: PSILLOS, c. d., s. $142-143$. 
Peirceho doložil, že termíny „hypotéza“ a „abdukce“ nejsou vždy tímto myslitelem používána jako synonyma. Abdukce slouží k pojmenování logické operace směřující k přijetí určité hypotézy. Zde však naráží na paradox, na který jsme již částečně poukázali. Na jednu stranu totiž Peirce tvrdí, že „,hypotéza je výsledkem úžasné imaginativní lidské schopnosti a současně, že je produktem speciálního druhu logické inference " ${ }^{61}$ Rozbor Peircova návrhu logické struktury abdukce jej pak vede k závěru, že abdukce nepopisuje proces nalezení hypotézy. Hypotéza (možné vysvětlení, „A“) se totiž objevuje již v premise abdukčního úsudku a závěr toliko konstatuje, že je ,podložené se domnívat, že toto vysvětleni je pravdivé “. 62 Model proto nezachycuje proces generace hypotézy, nýbrž ukazuje, jak je určitá hypotéza príijímána jako pravděpodobné řešení určitého problému, resp. jako „pracovní hypotéza“ (working hypotheses) ${ }^{63}$ hodna dalšího - již induktivního - testování. Nicméně nastavený filtr pro výběr této nejpravděpodobnější hypotézy je prŕliš široký, spiše dle názoru Frankfurta představuje pouhý „,inteligentní odhad“ (guessing intelligently) ${ }^{64}$ a v důsledku popisuje proces, jakým je určitá hypotéza zařazena mezi další možná vysvětlení určitého fenoménu. ${ }^{65}$

V reakci na tyto argumenty došlo k rozšsěpení či určité dvojkolejnosti v soudobých výzkumech abdukce: Část myslitelů se soustředí na proces generování hypotéz, tedy pokračuje v bádání Peircovy „meta-abdukce“. Klíčovou osobností, která stála u základů této větve zkoumání, byl americký filozof Norwood Russell Hanson (1924-1967), jenž v 50. letech 20. století jako první upozorňuje, že Peircova meta-abdukce zkoumá „logiku objevu“, tedy Reichenbachem popsaný „,kontext objevu“, u něhož Peirce předpokládal, že je dán určitými pravidelnostmi, jež lze rozkrýt. 66

Druhá větev se pak zaměřuje na způsoby výběru nejlepšího možného závěru (vysvětlení) určité situace a je spjata zejména se jménem dalšího amerického filozofa Gilberta Harmana (nar. 1938). Harman místo abdukce razí i nové označení - „odvození nejlepšího výsledku“ (inference to the best explanation) ${ }^{67} \mathrm{~V}$ rámci tohoto proudu je vynakládáno úsilí jednak na vytváření nových, adekvátnějších schémat zachycujících abdukční inferenci, jednak na hledání a formulování subtilnějších filtrů pro výběr nejlepš́ího možného vysvětlení. Jednotlivé návrhy se přitom navzájem prolínají, nicméně v současné době neexistuje shoda, co do jejich podoby.

61 FRANKFURT, H. G. Peirce's Notion of Abduction. The Journal of Philosophy. Columbia University, Vol. 55, No. 14 (Jul. 3, 1958), s. 594.

62 FRANKFURT, c. d., s. 594-595.

63 FRANKFURT, c. d., s. 595.

64 Oporu vidí v Peircově tvrzení, že z nekonečných vysvětlení určitého fenoménu má „lidský mozek takovou schopnost uhádnout správnou hypotézu dřive, než rada z nich bude testována, ... ponechává většinou neprozkoušenou" (FRANKFURT, c. d., s. 596, citováno je: CP 6.530, viz též výše).

${ }^{65}$ FRANKFURT, c. d., s. 597. Přehliženo je tedy to, že Peirce formuloval konkrétní kritéria, jež mají vést $\mathrm{k}$ výběru dobré vysvětlující hypotézy.

66 HANSON, N. R. Notes Towards a Logic of Discovery. In: BERNSTEIN, R. J. (ed.). Perspectives on Peirce: Critical Essays on C. S. Peirce. New Haven - London: Yale University Press, 1965. Do tohoto proudu by spadaly v poslední době populární výzkumy lidské intuice a různých heuristik při rozhodovacích procesech, které dokládají existenci určitých obecnějších kognitivních vzorců, které jsou využívány při , ,intuitivním myšleni", jež hraje nezastupitelnou roli „, nejistých“" př́ípadech, kdy ,jednotlivec spekuluje nad nejlepši možnosti" "SIČÁKOVÁ-BEBLAVÁ, E. In: GÁBRIŠ, T. Nedogmatická právna veda. Od marxismu po behaviorálnu ekonómiu. Praha: Wolters Kluwer, 2017, s. 208).

67 Tento proud tedy rozvíjí Peircem postulovaná kritéria pro výběr dobré vysvětlující hypotézy. 
Co se týče logické schematizace, tak k nejpopulárnějším návrhům patří řešení navržené Josephsonem a Josephsonem, kteří strukturují abdukční usuzování takto:

„D je souborem dat/fakti̊/pozorovaných skutečností.

$H$ vysvětluje $D$.

Žádná jiná hypotéza nevysvětluje D stejně dobře jako $H$.

Proto H je pravděpodobně pravdivé."68

Recentně lze pak třeba upozornit na schematizaci právníka a logika S. Brewera, jenž má za to, že k odvození nejlepšího vysvětlení dochází v těchto čtyřech postupných krocích:

„(i) identifikace určitého fenoménu, jenž má být vysvětlen (explanandum);

(ii) vyřčení několika alternativnich, logicky relevantnich a možných vysvětlení tohoto fenoménu (plausible-explanans);

(iii) identifikace nejlepšiho vysvětlení, a to... mj. při zohlednění zájmů a účelů argumentujici osoby, ${ }^{69}$

(iv) konstatování, že z dostupných vysvětlení jde o nejlepši možné vysvětlení dané věci."70

Stran kritérii pro nalezení nejlepšího řešení jsou vytvářeny různé katalogy, které zachycují různé atributy, jež jsou př́iznačné pro optimální hypotézy a jež současně ad hoc mohou přispět k nelezení nejlepšího vysvětlení. Konkrétně řečeno, zmiňovány jsou vlastnosti jako: (i) úplnost, tedy schopnost navrhované hypotézy vysvětlit všechna relevantní pozorovaná fakta, přičemž sama o sobě nevyžaduje další vysvětlení. Dále (ii) síla, jež se odvíjí od schopnosti hypotézy vysvětlovat i další obdobné př́ípady. K atributům nejlepší hypotézy však již nepatří, pokud je př́liš široká, tzn. do jejího explikativního rámce spadají i nesouvisející pozorované př́ípady. Negativně je tak kladen požadavek na (iii) úzkou aplikovatelnost (skromnost) navrhovaného vysvětlení, čímž se má zabránit zbytečným paušalizujícím závěrům, jež nemají oporu v pozorovaných faktech. Poukazuje se rovněž na vhodnost formulování pokud možno (iv) jednoduchých či spíše úsporných hypotéz v duchu Ockhamovy břitvy. (v) Preferována by rovněž měla být taková hypotéza, která v největší možné míře respektuje obecně uznávaný rámec dané vědní disciplíny, pokud neexistují pádné důvody pro jeho zpochybnění. Hypotéza má tedy být „konzervativní“. Měla by být i (vi) „relevantni““ (dobrá), tj. mít nějaký racionální vztah k vysvětlovanému fenoménu. ${ }^{71}$ Nelze rovněž opomenout (vii) verifikovatelnost, když od stupně opory v empirických důkazech se odvíjí významnost konkrétního návrhu vysvětlení. 72

68 Převzato dle: SINNOT ARMSTRONG - FOGELIN, c. d., s. 196.

69 Je nasnadě, že tyto zájmy se mohou lišit, a to dle jejich úhlu pohledu a postavení, které zaujímají. Tedy např́iklad jinak si bude tentýž fenomén vykládat žalobce, jinak žalovaný (srov. dále).

70 BREWER, c. d., s. 131-132. Brewer upozorňuje, že v rámci kroků (ii) a (iii) mohou být využívány i další základní módy inferencí jako dedukce či indukce, přičemž jejich kvalita se promítá i do relevance finálního vysvětlení. Například matematické, na dedukčních inferencích založené, vysvětlení bude nevyvratitelné, a to na rozdíl od probabilistických vysvětlení opírajících se o indukci. Blíže: BREWER, c. d., s. 135 a násl.

71 Na tento aspekt upozorňoval ve svých pracích již Peirce. Kupříkladu stř́iání dne a noci lze vykládat pravidelnou poutí boha Re po obloze a v podzemí, nicméně z pohledu dnešní nauky nejde o „dobrou“ hypotézu.

72 Tyto atributy zmiňují SINNOT ARMSTRONG - FOGELIN, c. d., s. 198-200. 
Uvedené vyžaduje doplnění $\mathrm{v}$ několika směrech: Předně je nasnadě, že popsaná kritéria se v mnohém překrývají s těmi, které již dříve formuloval samotný Peirce. ${ }^{73}$ Dále nelze přehlédnout, že tyto zásady představují pouze určité ideály, ke kterým se jednotlivá navrhovaná vysvětlení ve větši či menší míře přibližují. Je to částečně dáno tím, že kritéria se navzájem ve svých ryzích podobách vylučují. Patrné je to zejména na požadavku úzké aplikovatelnosti na straně jedné a síly na straně druhé. Dále je třeba po vzoru S. Brewera zdůraznit, že každé vysvětlení je vždy nerozlučně spjato se zorným úhlem osoby, která jej činí, popř. s určitým kontextem, do kterého má být zasazeno. ${ }^{74}$ Můžeme proto hovořit o morální abdukci (tj. o nejlepším vysvětlení z pohledu morálky), logické abdukci, kauzální abdukci, filozofické abdukci, či konečně - z pohledu této práce stěžejní - právní abdukci (nejlepší vysvětlení z pohledu práva). Dostáváme se tak ke klíčovému momentu: Jaký vlastně význam mají tyto úvahy ve vztahu k právu a právní vědě?

\section{PRÁVNÍ DIMENZE ABDUKCE}

Díváme-li se na právo a jeho realizaci optikou abdukce, stává se zřejmým, že rovněž v právním světě téměř na každém kroku zanechává svi̊j otisk. Neoddělitelnou součástí práce právníků je totiž přijímání různých vysvětlujících hypotéz. Prezentované poznatky o abdukci (ale i modelu vědeckého objevu) proto mohou přispět $\mathrm{k}$ lepšímu uvědomění i strukturaci těchto činností, jakož i k výběru vhodnějšího vysvětlení.

V právní praxi se přitom obvykle s vytvářením a výběrem vysvětlujících hypotéz setkáváme ve třech typově základních situacích: Zaprvé, abdukce bývá prováděna $\mathrm{v}$ rámci pokusů o rekonstrukci skutkového stavu věci rozhodného pro určitý právní případ (kauzální, skutková abdukce). Kupř́kladu kriminalista, který se dostaví na místo činu, se snaží z nalezených důkazních prostředků, mnohdy jen nepř́mých indicií, formulovat nejlepší možné vysvětlení toho, co se zde v minulosti odehrálo. Možné vysvětlení (tedy vysvětlující hypotéza přijatá na zkoušku) přitom předurčuje podobu jeho dalšího vyšetřování. Kriminalista si tedy bude zpravidla klást otázku, jak by se v obklopujícím světě projevilo chování určitého pachatele, a to pokud bychom vycházeli z hypotézy přijaté na zkoušku. Bude tedy - dedukčně - vyvozovat možné konsekvence určitého chování, jež posléze může - indukčně - ověřovat (např. provede rekonstrukci, prověrku na místě, vyšetřovací pokus ${ }^{75}$ ). Dodejme, že i v př́ipadě doznání pachatele by měl ověřit, zda v úvahu nepřichází jiné vhodnější abdukční vysvětlení rozhodné situace. ${ }^{76}$ Pokud bychom pozornost obrátili na soudy, tak je nasnadě, že i ony v rámci posuzování skutkových otázek využívají abdukční usuzování. V civilním řízení sporném soud ob-

73 Dodejme, že Peirce již ve svém prvním návrhu abdukce upozorňoval na to, že hypotéza by měla být vždy jasně stanovena a odlišena od pozorovaných jevů. K výběru hypotézy je pak třeba vždy přistupovat nestranně a najdeme-li protiargument, je třeba tuto skutečnost ,upř́mně príznat“ (PEIRCE, c. d., s. 476).

$74 \mathrm{~K}$ úhlu pohledu srov. blíže: BREWER, c. d., s. 129-131.

75 Srov. § $104 \mathrm{c}-\S 104 \mathrm{e}$ zákona č. 141/1961 Sb., o trestním řízení soudním, v platném znění (dále jen „tr. ř́d").

76 Srov. § 2 odst. 5 věta druhá tr. řádu: ,(d) oznání obviněného nezbavuje orgány činné v trestním rízení povinnosti přezkoumat všechny podstatné okolnosti př́padu“. 
vykle vybírá mezi vysvětlujícími hypotézami, jež mu podává žalobce na straně jedné a žalovaný na straně druhé. ${ }^{77}$ Svůj výběr opře o výsledky dokazování (indukce), které vede a $\mathrm{v}$ rámci kterého mj. obsahem svých otázek vyslýchaným osobám (svědkům, znalcům i účastníkům řízení) testuje správnost predikcí ohledně skutkového stavu, které by bylo možné vyvodit z tvrzení stran (dedukční fáze). Zda jeho abdukce, tj. volba jedné z konkurujících hypotéz, bude správná, může v př́ipadě podání opravného prostředku následně verifikovat odvolací soud. Obdobně postupují i trestní soudy, s tím rozdílem, že pokud nalezenou nekonzistenci či nedostatečnou provázanost v obžalobě, postupují v souladu se zásadou „in dubio pro reo“. Jak si ale výstižně všímá T. Sobek, soudce $\mathrm{v}$ obou př́padech ,si vlastně vytvárí svoji teorii (svioj př́běh) tohoto případu, kterou se snaží ,vybalancovat' do celkové koherence. Přitom koherence je obvykle chápána tak, že znamená jednak konzistenci, dále zahrnutí všech relevantnich zjištěných faktü, plus jejich vzájemnou provázanost, kdy jeden fakt podporuje druhý... "78 Jinými slovy, soudcovo vlastní abdukční vysvětlení rozhodných skutečností slouží jako filtr pro výběr relevantnější vysvětlující hypotézy, kterou navrhují soudní strany, a stojí i u základu toho, co bývá tradičně označováno jako „volné hodnocení důkazů“.

V kontextu výše prezentovaných úvah je přitom nasnadě, že postulovaná soudcova „volnost“" nemůže být libovůlí, nebot' abdukce předpokládá výběr takového řešení, které nejlépe splňuje určitá racionalizační kritéria tak, jak navrhoval Peirce a jeho následovníci. ${ }^{79}$ Pokud bychom přisvědčili opaku, a tedy za možné bychom považovali přijetí jakéhokoliv spekulativního vysvětlení, pak bychom de facto legitimizovali arbitrární, resp. i iracionální postup soudce při hodnocení důkazů, jakož i při řešení skutkových otázek. Vyřčený závěr přitom odpovídá názorům formulovaným $v$ judikatuře tuzemských vyšších soudů, dle kterých „(p)odstatou volného hodnocení dukazů je ... myšlenková činnost soudce, kterou tvoři takové elementy, jako jsou např. prüměrné životni zkušenosti každého člověka, osobní životni i profesní znalosti a zkušenosti soudce a zvláštní poznatky zjištěné při projednávání konkrétní věci..." (z odůvodnění nálezu Ústavního soudu ze dne 27. 3. 2017 ve věci sp. zn. ÚS 4266/16). ${ }^{80}$ „Uplatněni (zásady volného hodnocení důkazů - pozn. aut.) je... neoddělitelně spjato s požadavkem transparentnosti rozhodování, spočívajícím v povinnosti di̊kazni postup vyčerpávajicím způsobem popsat a logicky $\boldsymbol{i}$ věcně přesvědčivým způsobem odůvodnit..." (z odůvodnění nálezu Ústavního soudu ze dne 8. 7. 2014 ve věci sp. zn. II. ÚS 2564/12, zvýrazněno aut.). Lze

77 Nelze však vyloučit situace, že se strany na skutkových otázkách shodnout. Budou se však rozcházet v názorech na jejich právní posouzení.

78 SOBEK, c. d., s. 184.

79 Nutno však upozornit, že v rámci volného hodnocení důkazů se soudce pohybuje nejenom v mantinelech Peircem popsané racionality, a tedy při zjištování skutkového stavu postupuje mj. v souladu s koherenční teorií pravdy, jak ve výše citované pasáži akcentuje T. Sobek. Neméně důležité jsou mantinely, které pro soudce vyplývají z platného práva. Za príijatelnou vysvětlující hypotézu o určitém skutkovém stavu tak bude možné označit pouze takovou abdukci, která respektuje zákonné požadavky kladené na způsob získávání a provádění důkazních prostř̌edků. Kupř́íkladu seznámí-li se trestní soudce s odposlechem, který nebyl získán zákonným způsobem, nemůže k němu přihlédnout, a to má-li být jeho závěr „,nejvhodnější“, ačkoliv bude subjektivně přesvědčen o tom, že obžalovaný je vinen. K zákonným mantinelům by dále patřily i různé fikce a nevyvratitelné domněnky. $K$ odposlechům a dalším záznamům telekomunikačního provozu v tuzemském právu srov. $\S 88$ a násl. tr. rádu.

80 V citované pasáži lze hledat paralelu mezi Peircem popsaným požadavkem na zohledňování kontextu (zkušenostního, vědomostního apod.). 
mít za to, že Peircem a jeho následovníky představená kritéria výběru nejlepšího vysvětlení mohou být pro právníky inspirativní v tom směru, že nabízí konkrétní instrukce, jak podpořit „přesvědčivost i logičnost“ (byt' zřejmě chápanou ne striktně formálně-logicky), a tedy i pro-systémovost prijímaných závěrů o skutkových otázkách (srov. dále).

Zadruhé, abdukční inference lze hledat nejenom za rozkrýváním skutkových otázek. Neméně významnou roli hraje i v rámci zkoumání (hodnocení) zjištěného skutkového stavu prizmatem platného práva, a to ve snaze přiřadit nejvhodnější právní kvalifikaci. Můžeme proto hovořit i o právní abdukci. Vrátíme-li se $\mathrm{k}$ výše řešenému př́kladu, kriminalista bude zkoumat, které znaky trestného činu byly naplněny určitým chováním, popř. zda je vůbec na místě trestněprávní kvalifikace určitého chování. Taktéž advokát, seznamuje-li se s novým př́padem, usiluje nalézt nejpřesvědčivější a pro klienta nejvýhodnější právní vysvětlení skutkového stavu, který je mu předložen. Právní abdukce je prováděna i soudy, prričemž v kontinentálním typu právní kultury jsou to primárně ony, kdo závazně přiřazuje a hodnotí právní konsekvence posuzované věci. Pro orgány aplikující právo je charakteristické, že usilují o řešení, které je jimi vnímáno jako objektivně nejadekvátnější. ${ }^{81}$

Právní abdukce vždy vyrůstá z předchozích skutkových zjištění. Současně ale reguluje proces dokazování, ba je dokonce způsobilá přispět k modifikaci vstupně přijaté kauzální abdukce. Exponuje totiž právně relevantní konsekvence určitého jednání, jež je třeba v rrízení dokázat a $\mathrm{k}$ nimž lze dospět cestou logické dedukce, a to má-li být daná právní kvalifikace udržitelná. Jinak řečeno, ukazuje, která fakta je třeba prokázat, aby bylo možné podřadit určité chování pod zvažovanou právní normu. ${ }^{82}$ Pokud nenajde na zkoušku přijatá právní kvalifikace v rámci indukčního dokazování svoji oporu v důkazních prostředcích, je na místě jiné právní posouzení dané otázky, než bylo účastníky řízení navrhováno a/nebo zprvu orgánem veřejném moci zvažováno. Regulativní povaha právní abdukce se projevuje ještě v jednom ohledu, na který upozornil Peirce: nutí jednotlivce postupovat tak, jako by navrhované právní vysvětlení bylo pravdivé a jediné možné. Soud aplikující právo, bude-li tedy jeho právní abdukce podpořena i výsledky důkazního rrízení, rozhodne v souladu s tím, co vyplývá z jím vybrané právní kvalifikace. Nevylučuje to, že $\mathrm{v}$ rámci následného soudního přezkumu může být zvolené právní vysvětlení revidováno. ${ }^{83}$ Tato možnost bude ale minimalizována, pokud orgán aplikující právo bude zohledňovat kritéria výběru nejlepšího právního řešení, která byla vyslovena

81 Pokud by soudce stranil určitému účastníku řizení, popř. by pro to existovaly důvodné indicie, je na místě vznesení námitky podjatosti.

$82 \mathrm{~V}$ pozadí této teze stojí názor, že mezi světem faktů a světem norem od samého počátku soudního řízení existuje úzká interakce. V tuzemském právním prostředí tento úzký vztah plasticky popsal M. Šejvl, který upozorn̆uje, že aplikující orgán zahajuje dokazování se zřetelem k žalobnímu petitu a v něm provedené právní kvalifikaci. Fakta jsou tedy sbírána orgánem veřejné moci od počátku ,s ohledem na právní normu, kterou na ně hodlá aplikovat" (ŠEJVL, M. Jak udělat spravedlnost slovy. In: GERLOCH, A. - MARŠÁLEK, P. (eds.). Problémy interpretace a argumentace v soudobé právni teorii a právní praxi. Praha: Eurolex Bohemia, 2003, s. 184 a násl.). Dále srov. též MARŠÁLEK, P. Právo a společnost. Praha: Auditorium, 2008, s. 164.

83 Např́klad jedním z důvodů pro podání odvolání v civilních věcech může být fakt, že „rozhodnutí soudu prvního stupně spočivá na nesprávném právním posouzeni"“ (§ 205 odst. 2 písm. g) zákona č. 99/1963Sb., občanský soudní řád, v platném znění, což dokládá skutečnost, že právní abdukce umožňuje vyslovit jen možný - non-monotonický - závěr (srov. dále). 
ve vztahu ke kauzální abdukci (ač lze uvažovat o jistých modifikacích zohledňujících mj. požadavky plynoucí z platného práva či obecných zásad právních ${ }^{84}$ ).

Zatřetí, právní abdukce umožňuje nalézt právní filtr, přes nějž má být nahlíženo na určité právně-relevantní okolnosti. Nicméně takto identifikované právní ustanovení nemusí být vždy jasné a srozumitelné, a proto bude na místě provedení tzv. interpretační abdukce čili nalezení nejlepšího možného vysvětlení daného ustanovení z pohledu práva. V návaznosti na dř́ve uvedené přitom můžeme jakýkoliv vysvětlovaný normativní právní text (explanandum) pojímat jako určitou nepravidelnost, která vyvolává u exegeta údiv či významovou pochybnost, jež lze odstranit cestou interpretace sensu stricto ${ }^{85}$ Spouštěčem může být bud' jazyková nedostatečnost normativního právního aktu způsobená jeho mnohoznačností (např. použitím homonym, amfibolií, konfúzí neurčitostí $)^{86}$ či neurčitostí, anebo exegetovo přesvědčení, že interpretační závěr, ke kterému dospěl při použití pouze jazykové metody výkladu, je nesprávný, nepřiléhavý, nevhodný, a to je-li zohledněn i jiný než čistě jazykový kontext (např. tedy hodnotový). ${ }^{87}$ Podstata interpretační abdukce $\mathrm{v}$ př́ípadě nedokonalosti jazyka spočívá v tom, že interpretační závěr získaný zejména na základě jazykové metody se jeví jako nedostatečný pro formulaci obsahu právní normy rozhodné pro posuzovaný př́ípad, a je tedy třeba jej dotvořit pomocí dalších metod právní interpretace (např. metody historické, teologické). Nelze přitom vyloučit, že jednotlivé metody budou vybízet k rozdílným řešením, a tudíž součástí interpretační abdukce bude i volba mezi dílčími interpretačními závěry. $\mathrm{V}$ druhém př́padě pak z povahy věci exeget vybírá mezi několika v úvahu přicházejícími interpretačními výsledky, k nimž dospěl na základě standardních metod právní interpretace na straně jedné a nadstandardních metod na straně druhé. ${ }^{88}$

V současné době se tuzemská právní nauka víceméně shoduje na obsahu jednotlivých dílčích metod interpretace práva, a lze tedy hovořit o jisté „ustálenosti“ používaných metod. ${ }^{89}$ Nicméně totéž již nelze vyslovit o metodologii právní interpretace jako celku, a to je-li pojímána jako soubor výkladových pravidel prvního a druhého stupně. ${ }^{90}$ Jed-

84 Jako př́iklad může posloužit již dříve zmíněna zásada in dubio pro reo. Srov. dále též poznámka pod čarou č. 80 .

85 K rozlišování interpretace sensu stricto a sensu largo srov. J. Wróblewski in: LANG, W. - WRÓBLEWSKI, J. - ZAWADZKI, S.: Teoria państwa i prawa. Warszawa: Państwowe Wydawnictwo Naukowe, 1976, s. 399 a násl. V tuzemské literatuře pak zejména: ŽÁK KRZYŽANKOVÁ, K. Právní interpretace - mezi vysvétlováním a rozuměním. Praha: Wolters Kluwer, 2019, s. 9-75.

$86 \mathrm{~K}$ důvodům mnohoznačnosti srov. ŠTĚPÁN, c. d., s. 17-18.

87 Je nasnadě, že první z naznačených př́čin vzniku nejasností, tj. přirozená neostrost a nepřesnost jazyka, ve kterém jsou formulovány právní texty, má spíše objektivní povahu, kdežto druhý důvod, spočívající ve skepsi exegeta ohledně spravedlnosti, správnosti či účelnosti určitého ustanovení, jež u něj po čistě jazykové stránce nevyvolává žádné pochybnosti, může být zatížen subjektivním pohledem a postoji interpreta. O tom, zda druhý typ spouštěčů pochybností bude přicházet v úvahu, rozhoduje v dané interpretační komunitě převládající „,ideologie aplikace práva“. K ideologiím aplikace práva srov. KÜHN, Z. Aplikace práva ve složitých prípadech. K úloze právních principư v judikatuře. Praha: Karolinum, 2002, s. 232-246.

88 K rozdělení metod právní interpretace na standardní a nadstandardní, jakož i k jednotlivým metodám srov. GERLOCH, A. Teorie práva. 7., aktualizované vyd. Plzeň: Vydavatelství a nakladatelství Aleš Čeněk, 2017, s. 144 a násl.

89 Blíže: HLOUCH, L. Teorie a realita právní interpretace. Plzeň: Vydavatelství a nakladatelství Aleš Čeněk, 2011, s. 213.

90 Interpretační pravidla prvního stupně určují, jak vykládat normativní právní text z pohledu jazyka, systému, historie vzniku apod. Kdežto interpretační pravidla druhého stupně stanoví, která z pravidel prvního stupně lze aplikovat, $v$ jakém pořadí a konečně jaké z pravidel prvního stupně upřednostnit v př́ípadě jejich 
notlivé přístupy k právní interpretaci, byt’ rozlišují obdobné výkladové metody (tj. výkladová pravidla prvního stupně91), mj. odlišně řeší, kdy vlastně začíná a kdy končí interpretační proces ${ }^{92}$ a zda právní interpretace je součástí obecné humanitněvědní interpretace zaměřené na rozkrývání významového svazku (nexus of meaning, Sinnzusammenhang) interpretovaného objektu, ${ }^{93}$ anebo zda má svá specifika dávající eventuálně prostor pro uplatnění dekonstrukce textu prostřednictvím teologické metody výkladu. Rozcházejí se rovněž v názorech, jaké vztahy existují mezi jednotlivými metodami či třeba jak řešit jejich př́ípadné kolize, tj. kdy se dílčí interpretační závěr získaný při využití jedné výkladové metody liší od jiného dílčího interpretačního výsledku, $\mathrm{k}$ němuž interpret došel pomocí jiné metody. Doktrína se tedy neshoduje na obsahu interpretačních pravidel druhého stupně. Nejednotná je i právní praxe, byt’ nelze přehlédnout významnou roli, kterou hrají vyšší soudy při vytváření kritérií pro výběr optimálních interpretačních závěrů v rámci sjednocování judikatury a celkového přezkumu rozhodnutí nižších soudů.

Neexistence ucelené metodologie interpretace práva znesnadňuje provádění interpretační abdukce jako pro-systémové činnosti. Nelze totiž nevidět, že od míry ustálenosti i akceptovatelnosti metodologie právní interpretace odvisí stupeň systémovosti provádění právního výkladu (interpretační abdukce) v právní praxi. Po vzoru Bergera s Luckmannem lze dokonce vyslovit názor, že nejednotnost praxe pramenící z plurality interpretačních teorií a jimi formulovaných metodologických katalogů může vést $\mathrm{k}$ destabilizaci existujícího právního řádu i společenské homeostázy, kterou ve značném stupni pomáhá udržovat. ${ }^{94} \mathrm{~K}$ významným úkolům právních vědců by proto mělo patřit zkoumání interpretačních pravidel druhého stupně a následně jejich předávání studentům $\mathrm{v}$ rámci jejich př́pravy $\mathrm{k}$ právním povoláním, kdy tyto znalosti by se takto mohly stát součástí Peircem popsaných background-beliefs, které - jak bylo výše vysvětleno - hrají nezastupitelnou roli ve vytváření i přijetí dobré vysvětlující hypotézy. ${ }^{95}$

vzájemné kolize. K tomuto dělení, jehož autorství je připisováno J. Wróblewskému, srov. v podrobnostech v tuzemské literatuře WINTR, J. Metody a zásady interpretace práva. Praha: Auditorium, 2013, s. 168 a násl.

91 Neznamená to však, že se ve všech dílech objevují vždy materiálně identické metody výkladu, popř. že budou v aplikační praxi stejně vykládány a aplikovány. Za zvláštní pozornost pak stojí skutečnost, že nedávno tuzemský normotvůrce částečně reguloval tato pravidla v §§ 2-13 nového občanského zákoníku (zákon č. 89/2012 Sb.).

92 Metodologie interpretace sensu largo cílí na částečně odlišné poznávací procesy než metodologie zaměřená pouze na interpretaci sensu stricto.

93 „Významový svazek“ určitého textu je dán vědomým i nevědomým užitím znaků ze strany autora, resp. i dalším textuálním kontextem - historickým, kulturním a autorským. Blíže: HIRSCH, E. D. Validity in Interpretation. New Haven and London: Yale University Press, 1967, s. 7 a násl.

94 Pluralita vždy odhaluje, že ,(v)šechny společenské reality jsou nejisté. V̌sechny společnosti jsou jen konstrukty čelící chaosu. Neustále hrozíci nebezpeči anomického děsu propukne naplno, kdykoliv jsou legitimizace, jež tuto nejistotu zastírají, ohroženy nebo se zhrouti" (BERGER - LUCKMANN, c. d., s. 104). Na druhou stranu, jak správně upozorňuje M. Škop, jen dekonstrukce právní vědy/práva umožňuje ,nabidnout obraz teorií, jako zatižených určitými ideologiemi...", které nemusí být nadále vnímány jako dostatečné, čímž je dán prostor pro různé ,opravy, náprav(y) či vylepš(ení)“, tedy pro ,přizpưsob(ení) teorie vnímání tohoto druhého a privést je zpět do práva“ (ŠKOP, M. Dekonstrukce jako metoda poznání práva. [online, cit. 25. 6. 2019]. Dostupné na: https://www.law.muni.cz/sborniky/dp08/files/pdf/prteorie/skop.pdf).

$95 \mathrm{~V}$ tomto bodě se tak Peircovy úvahy protínají s hermeneutickými koncepcemi hovořícími o ,předporozuměni““, ,předvědění“ a dalších ,předsudcích.“ V podrobnostech srov. GADAMER, H.-G. Pravda a metoda. Nárys filozofické hermeneutiky. Praha: Triáda, 2010, s. 240 a násl. 
Rovněž u interpretační abdukce nelze přehlédnout její regulativní charakter. $\mathrm{K}$ interpretačnímu závěru, který je soudem vybrán jako optimální, je následně soudcem přistupováno tak, že je v dané situaci jediný možný a promítá se i do způsobu a obsahu finálního rozhodnutí. Je-li vskutku toto subjektivní soudcovo přesvědčení o pravdivosti daného výkladu a z něho dovozené právní konsekvence oprávněné, může být následně testováno $\mathrm{v}$ rámci přezkumných řízení. Bude-li akceptováno $\mathrm{v}$ dané právní komunitě, lze hovořit o jeho správnosti a platnosti. Nicméně nelze vyloučit, že $\mathrm{v}$ budoucnu dojde k odklonu, tedy nalezení vhodnější interpretační abdukce (viz dále). ${ }^{96}$

$\mathrm{V}$ neposlední řadě je třeba poukázat na to, že rovněž v právně-teoretickém usuzování, a to je-li hledáno nejlepší vysvětlení různých právně-relevantních společenských fenoménů, právních institutu či pouze jednotlivých zákonných ustanovení, má kauzální, právní i interpretační abdukce své nenahraditelné místo. ${ }^{97}$ Právní věda recentně stále častěji obrací svoji pozornost i na problém „meta-abdukce“, kdy mj. je zkoumána role intuice či různých heuristik $\mathrm{v}$ rozhodovacích procesech, a jak lze jejich obsah formovat $\mathrm{v}$ rámci právní socializace..$^{98}$

\section{ZÁVĚR}

Analyzujeme-li jednotlivé varianty abdukčních vysvětlení podávaných představiteli právní obce, nelze si nevšimnout, že vykazují určité společné znaky, které jsou typické pro abdukční inference jako takové a které již byly částečně představeny výše v první části příspěvku.

Předně je tedy patrná jejich non-monotonická povaha. Jinak řečeno, naprostá většina přijímaných vysvětlení má potencionálně zpochybnitelnou povahu. Není tedy pro ně př́iznačná neměnná platnost, jež by se automaticky odvíjela od dodržení určitého inferenčního algoritmu. $\mathrm{V}$ budoucnu je tedy možný významový posun, resp. přijetí jiné vysvětlující hypotézy. Př́značné je to zejména pro interpretační abdukční inference, kdy ani sedimentovaná praxe výkladu určitého ustanovení nevylučuje následnou reinterpretaci. ${ }^{99}$ Ve vztahu k abdukčním vysvětlením prrijímaným v individuálních věcech - jak jsme výše naznačili - je pak potencionální otevřenost abdukčního vysvětlení zachována do doby pravomocného završení věci, kdy se kauzální, právní i interpretační abdukce

96 Pramení to z toho, že v tuzemském právu soudní rozhodnutí nemají povahu obecně závazného rozhodnutí. V podrobnostech srov. však WINTR, J. Místo závaznosti judikatury v systému metodologie interpretace kontinentálního práva. In: ŠÁMAL, P. - RAIMONDI, G. - LENAERTS, K. a kol. Závaznost soudních rozhodnutí - vnitrostátní a mezinárodni náhledy. Praha: Wolters Kluwer, 2018, s. 87-95.

97 Posuzováno touto optikou tento př́spěvek představuje pokus o nejlepší možné vysvětlení abdukce.

98 Srov. poznámka pod čarou č. 67, jakož dále třeba: BROŻEK, B. Umyst prawniczy. Kraków: Copernicus Center Press, 2018.

99 Srov. $\mathrm{k}$ tomu $\mathrm{k} \S 13$ obč. zákoníku, dle kterého ,„(k)aždý, kdo se domáhá právní ochrany, může důvodně očekávat, že jeho právni př́pad bude rozhodnut obdobně jako jiný právni př́pad, který již byl rozhodnut a který se s jeho právním př́padem shoduje v podstatných znacich; byl-li právni prípad rozhodnut jinak, má každý, kdo se domáhá právni ochrany, právo na presvědčivé vysvětleni di̊vodu této odchylky". Primárně tedy nová soukromoprávní úprava počitá s tím, že soudci postupují shodně s ustáleným výkladem. Současně je ale zachována možnost nového pohledu na věc, který je však obhajitelný pouze tehdy, bude-li „přesvědčivě“ vysvětlen. 
promění v realitu přijímanou právem. ${ }^{100}$ Nicméně i z tohoto pravidla existují určité výjimky, a to v podobě mimořádných opravných prostředků, které dávají prostor pro revizi kauzálních i právních abdukčních závěrů.

Dále je třeba zmínit, že všechna podaná vysvětlení vždy alespoň zčásti reflektuje zorný úhel osoby, která jej činí, a který je dán zejména jejím postavením (akademik, advokát, obviněný či třeba soudce ${ }^{101}$ ), znalostmi a předchozími zkušenostmi, což z povahy věci subjektivizuje relevanci navrhované vysvětlující teze.

Na druhou stranu je třeba upozornit, že všechna navrhovaná právní vysvětlení získávají na přesvědčivosti, jsou-li subjektem zohledňována určitá kritéria pro výběr dobrých hypotéz, jež jsou v dané komunitě uznávána. $\mathrm{V}$ oblasti výkladu práva budou tato kritéria splývat s katalogy interpretačních pravidel lege artis, tedy metodologickými pravidly uznávanými v odborných kruzích za optimální. V oblasti právní nauky pak mohou být relevantní ta kritéria, která byla vypracována na půdě metodologie vědy a jejichž př́klady byly uvedeny výše. Totéž platí i ve vztahu ke kauzálnímu vysvětlení s tím, že důraz by měl být kladen i na koherenci s poznatky př́slušné fyzikální vědy. Znalost těchto kritérií102 a jejich dodržování objektivizuje procesy, ve kterých dochází $\mathrm{k}$ výběru nejlepšího vysvětlení a současně též snižuje jeho arbitrárnost a libovưli. Ve svém důsledku působí stabilizačně a pro-systémově.

Vede to pak $\mathrm{k}$ závěru, že úsilí právní obce by mělo být zaměřeno na systematické vytváření a propracovávání katalogů těchto kritérií, a to se zvláštním zřetelem na specifika práva a jeho realizace, jakož i na další zkoumání abdukčních inferencí. Nedílnou součástí právního vzdělávání by přitom mělo být předávání těchto poznatků novým generacím. Lze si od toho slibovat snížení prostoru iracionality, nahodilosti a fragmentárnosti v praktickém i teoretickém právním myšlení.

JUDr. Katarzyna Žák Krzyžanková, Ph.D.

Právnická fakulta Univerzity Karlovy

krzyzank@prf.cuni.cz

\footnotetext{
100 Je nasnadě, že právem akceptovaná ,realita“ se může lišit od skutečnosti, a to mj. z důvodu nutnosti respektování jistých právních mantinelů v rámci rozhodovacích procesů (viz výše - poznámka č. 80).

${ }^{101}$ Patrné je to zejména v soudních řízeních, kdy strany jsou silně zainteresovány na výsledku pře, což se promítá i do jimi podávaných abdukčních vysvětlení. Soudce - zopakujme - by pak měl usilovat o co nejracionálnější řešení, jež by a priori bezdůvodně nestranilo žádné ze stran.

102 Implicitním předpokladem je ale předchozí existence a alespoň relativní ustálenost takových pravidel.
} 